\title{
Understanding the Exclusionary Politics of Early Turkish Nationalism: An Ethnic Boundary-Making Approach
}

\author{
Gregory J. Goalwin \\ Department of Sociology, \\ University of California, Santa Barbara \\ Santa Barbara, CA, U.S.A.
}

Citation: Gregory J. Goalwin, "Understanding the Exclusionary Politics of Early Turkish Nationalism: An Ethnic Boundary-Making Approach," Nationalities Papers, June 12, 2017, 1-17, doi:10.1080/00905992.2017.1315394.

Final Published Version Available at: http://dx.doi.org/10.1080/00905992.2017.1315394

\begin{abstract}
:
Turkish nationalism has long presented a study in contrasts. The nationalist movement that created the Republic of Turkey sought to define the nation in explicitly civic and inclusive terms, promoting a variety of integrationist reforms. At the same time, however, those same nationalist politicians endorsed other policies that were far more exclusionary, expelling many religious and ethnic minorities from the new nation and imposing harsh restrictions on those who remained. The seemingly contradictory nature of Turkish nationalist policies has been mirrored by much of the scholarship on Turkish nationalism, which has often viewed Turkish nationality through the lens of the "civic/ethnic divide," with various scholars arguing that the Turkish nation is exclusively civic or ethnic. This article seeks to transcend this dichotomous way of looking at Turkish nationalism. I argue that the policies previously seen as being exclusively civic or ethnic are in fact both examples of boundary-making processes, designed to forge a cohesive nationalist community. Seen through a boundary-making perspective, the seemingly contradictory nature of Turkish nationalist policies in its early years are not paradoxical at all, but represent a multidimensional effort to construct a cohesive national community that could replace the defunct Ottoman state.
\end{abstract}

Keywords: Turkey, Civic Nationalism, Ethnic Nationalism, Boundary-Making 


\section{$\underline{\text { Introduction }}$}

The establishment of the Republic of Turkey entailed a significant amount of social and political turmoil as the Turkish nationalist movement sought to craft a new national community out of the wreckage of the Ottoman Empire. The nation that Turkish revolutionaries founded has long presented itself as self-consciously civic and territorial, seeking to draw sharp contrasts between what nationalists considered to be an antiquated Ottoman state and what would be a new modern nation-state. In keeping with this emphasis, Mustafa Kemal Atatürk and the other nationalists who founded the Turkish nation relied upon a rhetoric that argued for an inclusive form of national project in which all residents of Turkey would be considered Turks, so long as they were willing to be loyal to the new Turkish state. Yet despite this rhetoric, some of the new state's policies and the actions of the Turkish citizens on the ground belied such lofty inclusive and universalist definitions of national identity. A closer look at the development of the Turkish nation reveals the creation of a new national state with strong exclusionary boundaries and a distinct sense of a core Turkish ethnicity around which the nation was organized. This ethnicity encompassed, to greater or lesser degrees, elements such as religion, language and race, and scholars have noted that those who were Sunni Muslim, spoke Turkish, or were members of the Turkish race were considered to be "truer" Turks than those who were members of religious, linguistic, or racial minorities (Çağaptay 2006). Such a focus on the primacy of Turkish ethnic identity raises significant questions. If Turkish nationalists intended to craft a secular civic state, why did Turkey's early policies place such an emphasis on ethnic characteristics as markers of true Turkishness? How was a distinctive conception of Turkish identity, a new concept not previously used as a major basis of social organization during the Ottoman Empire, formed, and how did it become a politically salient characteristic in early Republican Turkey? How were the boundaries between Turks and non-Turks defined?

This article draws upon the ethnic boundary-making approach pioneered by scholars such as Fredrick Barth (1969) and extended most recently by Andreas Wimmer (2013). Such an approach examines how and why ethnic boundaries form and become politically salient. The ethnic boundary making approach can be effective in answering such questions because it seeks to understand how ethnic divisions come about and why people identify more strongly with specific categories of identification in specific circumstances and contexts, but not in others (Brubaker 2006). This perspective is particularly well suited to the study of Turkish nationalism and the ways in with ethnic boundaries became politically salient as signifiers of the national community. Following the chaotic collapse of the Ottoman Empire, Turkish nationalists were faced with the task of crafting not just a new state, but a new nation and sense of national identity as well. The political transformation that accompanied this transition brought with them a wealth of social and cultural changes as the multiethnic and multireligious Ottoman society was reconfigured into a national state with distinct ethnic and cultural boundaries. I argue that the prevalence of exclusionary ethnic definitions of Turkish nationalist identity, despite the movement's stated goal of crafting an inclusive civic national community, was the result of 
changes in the institutional milieu, the distribution of power, and the reach of social and political networks during the last years of the Ottoman Empire and the first decades of the Turkish Republic. Turkish nationalists believed that the institutional collapse of the Ottoman Empire mandated a transition to a more strictly bounded nation-state system, one that could be constructed on a "core" Turkish identity. This belief required the construction of a new sense of Turkish ethnicity, a process of ethnogenesis that would craft a national community inclusive enough to garner popular support but exclusive enough to both foster group cohesion and exclude potential enemies of the new state. The distribution of political power and the reach of social networks in the late Ottoman Empire and the early Republic of Turkey helped determine where the boundaries of the Turkish nation would form, ultimately dividing the former Ottoman population along religious lines, crafting a Turkish identity intimately intertwined with Sunni Islam, and excluding those who fell outside a rigidly bounded sense of what it meant to be Turkish.

\section{$\underline{\text { Rhetoric and Reality: Inclusive and Exclusive Conceptions of Turkish Nationalism }}$}

The classical approach to the study of nationalism often divides nationalist movements into those that emphasize civic approaches to national identity and those that rely on ethnic characteristics as the foundational element of the nation (Kohn 1944; Smith 1991; Brubaker 1992). In this perspective, civic nationalist movements are thought to be inclusive, territoriallybased, and explicitly non-ethnic, favoring common feeling and loyalty to the nation as constituent elements of national belonging over exclusionary characteristics such as ethnicity or religion. In contrast, ethnic nationalism has been portrayed as exclusionary, with only those sharing some sort of ethnic, racial, or religious bond being seen as "true" members of the national community. Often problematic, the two categories have been heavily value laden, with civic nationalism portrayed as the domain of the inclusive and liberal "West," while exclusive ethnic nationalism has been attributed to the irrational and backwards "East." Such a strict dichotomy has been increasingly challenged in recent years by scholars who have recognized significant problems in the classical formulation. Recent work on nationalism has forced scholars to come to grips with the Westocentric narratives that have so heavily influenced classical approaches to typologizing nationalisms, and has recognized that all nations contain both civic and ethnic components (Yack 1996; Brubaker 1999; Shulman 2002; Akman 2004).

This reconceptualization of the relationship between civic and ethnic variants of nationalism is particulary important for the study of nationalism in Turkey, which has long prided itself on its role as a gateway between East and West, a state with a predominantly Muslim population and a system of governance explicitly modeled on Western forms developed in France. The scholarly literature examining the development of Turkish nationalism has reflected this dual nature of Turkish society. Many of the seminal works on Turkish nationalism

and the development of its state have emphasized its civic characteristics. Works such as Bernard Lewis's The Emergence of Modern Turkey (1961), Niyazi Berkeş's The Development of Secularism in Turkey (1964), and later Feroz Ahmad's The Making of Modern Turkey (1993) 
have focused on the distinct break involved in social and political transition from the Oriental early-modern system of the Ottoman Empire to the new secular, civic, and Western Republic of Turkey. Scholars writing in both English and Turkish argued that territory and political allegiance have mattered far more in defining membership of the Turkish nation than have ethnic or cultural categorizations (Turan 1969; Kili 1983; Ahmad 2003). More recent works have questioned this perspective, however, observing the continuation of Ottoman understandings of the importance of ethnicity (Kirişci 2000; Uzer 2011; Xypolia 2016) and religion (Akturk 2009; White 2013; Grigoriadis 2013) even in a new Turkish state that had sought a radical break from the Ottoman past and imposed new ideas of secularism and civic nationalism. Ultimately, the new Turkish state worked to create a singular sense of national identity, creating a "monolithic nationhood" in which alternative understandings of Turkishness were suppressed in favor of a more restrictive national ideal (Al 2015).

The scholarly debate over whether Turkish nationalism is primarily civic or ethnic is a reflection of complicated political currents on the ground in Turkey. A close look at Turkish history reveals that its government has pursued policies that seem incompatible, alternately, and even concurrently, endorsing both civic and ethnic categories of identification (Aktürk 2012). Ultimately scholars have recognized that there are a variety of competing narrative discourses, each promoting a different understanding of what it means to be a true Turk, that have played an important role in constructing Turkish national identity (Poulton 1997; Bora 2003). From the beginning, the Turkish nationalist movement portrayed itself in civic and inclusive terms, characterizing the new state as modern, secular, and territorially focused, modeled on the laicist example of France (Hanioğlu 2011, 134). Reforms under the new state sought to promote a new variety of Turkish, modeled on the "rough" language of everyday citizens rather than the literary and official Ottoman variety of Turkish that had been prominent amongst the elite, as a common language of the new national community (G. Lewis 1999; Aytürk 2004). Simultaneously, Atatürk's revolutionary nationalists worked hard to strip religion of its role as the prime constituent factor of personal and group identity, seeking to replace it with political allegiance to the state and a national variety of Turkishness (Berkes 1964; Morin and Lee 2010). Such efforts were theoretically designed to promote national cohesion and establish a new nation, one that would integrate and incorporate a wide spectrum of the diverse former Ottoman population within an overarching framework of Turkishness.

The Turkish state's efforts to remove religion as a divisive basis for social organization, and policies designed to integrate minority populations within an overarching sense of civic Turkishness reveal the extent to which Turkish nationalists sought to craft an inclusive new national identity, one which could supersede many of the most important cleavages that had plagued Ottoman society. Yet at the same time as the Turkish government was implementing some integrationist policies, it pursued others that were far more exclusionary, working to isolate and eliminate minority populations in a way that placed a premium on Turkish ethnicity and adherence to Sunni Islam as defining characteristics of national identity. Before the Turkish state 
was officially founded, members of the ruling Committee for Union and Progress (CUP), many of whom would go on to hold important positions in Turkey's new government as members of Atatürk's Republican People's Party (CHP), initiated policies of seizure, deportation, and massacre of the Armenian population of Eastern Turkey in what has become known as one of the first modern genocides (Akçam 2012). Similarly, in the negotiations with Greece and other Western powers that established the new state, the Turkish government agreed to a population exchange in which all of the Greek Orthodox Christians living in Turkey who had not already fled with the Greek army would be "exchanged" for the Muslim population of nearby Greece (Yildirim 2006; Clark 2006), part of a region-wide outpouring of violence and "unmixing" that accompanied the collapse of the Ottoman Empire. Policies throughout the next few decades continually favoured those who were ethnically Turkish and religiously Sunni Muslim, to the disadvantage of ethnic and religious minorities. In such policies the Turkish state sought to create a homogenous new society, removing minority elements that were thought to be a potential threat to national sovereignty, and crafting a Turkey that was ethnically Turkish and religiously orthodox Sunni.

A close look at Turkish nationalism thus reveals that it has pursued policies that do not conform to the traditional civic/ethnic dichotomy. Simultaneously both inclusive and exclusive, civically focused but ethnically motivated, Turkish nationalism is multifaceted, as indeed, scholars are recognizing, so many other national communities are (Pearson 2000; Shulman 2004). Such findings reveal the complicated relationship between different measures of identity in Turkey and elsewhere, and suggest that the traditional Ethnic/Civic dichotomy is of limited use for those seeking to understand the development of national identity in Turkey ( $\mathrm{Al}$ and Karell 2016). This article thus seeks to transcend this traditional divide, focusing on not simply the civic or ethnic components of Turkish national identity, the inclusionary efforts at assimilation and the exclusionary politics of population exchange and ethnic cleansing, but analysing them both in tandem, seeking to understand how and why the Turkish state chose to include some populations while excluding others. I argue that such contradictory policies can best be analysed through an ethnic boundary-making framework. An approach emphasizing ethnic and national boundary formation reveals that, rather than illogical or paradoxical efforts, Turkish nationalist policies represent focused efforts to construct a bounded sense of national community, creating a new national identity that was inclusive enough to have wide popular support but exclusive enough to keep out minority communities deemed "dangerous" to national culture and homogeneity.

\section{Processes of Ethnic and National Boundary Formation}

At its core, the seemingly contradictory nature of Turkish nationalism, with policies appearing to alternate between inclusive civic and exclusive ethnic approaches to governance, reflects a struggle over how to define the boundaries of the nation, determining who should, and should not be, a member of the new national community. In his work, Andreas Wimmer has developed a model that both outlines and systematizes the boundary oriented approach to the 
study of ethnic groups, but also seeks to transcend it, developing a comparative analytic to understand how and why ethnicity matters in certain societies and contexts but not others. He explains that he intends to contribute to the advancement of the boundary-making tradition in the study of ethnicity

"by systematically exploring the different options that actors may pursue to react to existing boundaries, to overcome or reinforce them, to shift them to exclude new groups of individuals or include others, or to promote other, nonethnic modes of classification and social practice" (Wimmer 2013, 46).

Wimmer views nationalism as a specific type of ethnic boundary making. Though such an approach has received some criticism (Brubaker 2014) the common recognition that ethnicity often serves as a central core characteristic around which national identities form (e.g. Smith 1987) makes an ethnic boundary making approach suitable for the analysis of national boundaries as well.

For Wimmer, the formation of ethnic groups is largely the product of classification struggles over power in a particular social field. "In a nutshell," he explains, "the model explains the varying features of ethnic boundaries as the result of the negotiations between actors whose strategies are shaped by the characteristics of the social field" (Wimmer 2008a, 973). Within the social field three distinct characteristics - institutional order, the distribution of power, and the extent of political networks - determine where and how ethnic boundaries are formed. The institutional framework determines which types of boundaries can be drawn in a meaningful way, the position in a hierarchy of power defines the interests according to which actors choose between levels of differentiation and the structure of political alliances determines who will be included and excluded from the ethnic categories around which boundaries are drawn (Wimmer 2008a, 973). The institutional structure of the modern state provides significant incentive for ethnic formation. The bounded nature of modern states has encouraged states to create distinctive national ethnic groups and differentiate them from ethnic and other groups who are not to be considered members of the new national state community. The institutional structure of the modern state system thus encourages ethnic identification and the restructuring of social life around ethnic and national groups, which serve as the constitutive building blocks around which modern societies and political structures are formed. Meanwhile, the distribution of power in the social field provides a constraint on the types of strategies available for actors to use as they seek to impose their own sense of order on the world. Individuals' positions within the hierarchy of the social field determines which characteristics they will emphasize and around which level of ethnic differentiation they will choose to construct social boundaries, selecting those perceived to maximize the potential gain both within the ethnic group and vis-à-vis those outside the group. Finally, the extent of social networks helps determine where and when specific ethnic boundaries will be formed. Networks of political alliances can help determine where the boundaries between "us" and "them" are drawn. Under conditions with significant lines of political networks which transcend ethnic groups, ethnicity as such is less likely to by emphasized as a salient 
characteristic for group identity, while situations with a distinct lack of political linkages across ethnic lines are more prone to ethnic differentiation and the emphasis on ethnicity as a key facet of political and social life.

These three characteristics of the social field determine why, how, and where ethnic boundary-making will take place. With this in mind, Wimmer identifies a series of strategies that actors can pursue to establish new ethnic boundaries, shared mechanisms that govern ethnic boundary making across a wide variety of social and historical contexts. Such mechanisms include those that: 1) expand the number of people included; 2) contract boundaries and thus reduce the number of people they enclose; 3 ) seek to change the meaning of existing boundaries by challenging ethnic hierarchies; 4) attempt to cross boundaries by changing one's one categorical positioning; 5) And aim to overcome ethnic boundaries by emphasizing other crosscutting levels of identity through strategies of "boundary blurring" (Wimmer 2008a, 986). Wimmer's typology of modes of boundary making incorporates strategies of action that occur on a variety of levels. The first two modes Wimmer identifies involve the direct contestation of boundaries as groups and social organizations expand and contract existing social boundaries in their efforts to promote group solidarity and influence. Expansion involves the incorporation of outsider categories into the group, fusing together social categories to create a new sense of group identity. The processes of nation-building serves as one powerful example of this sort of strategy, as state elites struggle to create a new national identity that subsumes existing ethnic, cultural, racial, or linguistic boundaries within an overarching concept of the nation state. This can be done either by privileging a particular ethnic group that all members of the nation should strive to join, amalgamating a variety of ethnic groups into a single whole, or emphasizing a higher level of categorical distinction (Wimmer 2013, 50). Critically this process of nation formation often entails a concomitant process of ethnogenesis, both of the new national ethnicity, but also of ethnic minorities who cannot, or refuse to, fully integrate with the national majority. Conversely, contraction involves a drawing of tighter boundaries around the group, disidentifying with larger social categories in an effort to create stronger boundaries around a particular core constituency. This can be done through splitting the existing category in two or through shifting the emphasis to lower levels of differentiation in a way that more draws specific dividing lines around a subset of the category (Wimmer 2008b, 1037).

Wimmer's other three modes of boundary making do not involve direct contestation of existing boundaries, but instead seek to reconfigure an actor's position within existing boundary structures. The third mode seeks to transform normative conceptions of what ethnic boundaries mean by inverting them, such that outcast groups are seen as powerful and superior, or arguing for equality so that such outcast groups can share fully in systems of status and political power (Wimmer 2013, 57). The fourth method of boundary making involves boundary crossing at the individual level as individuals seek to shift between categories to avoid membership in disadvantaged social groups. Such strategies are visible in processes of assimilation, passing, and conversion, as individual actors strategically reposition themselves to maximize power and 
opportunity. The final mode of boundary work entails conceptual "blurring" in which ethnic categories are deemphasized in favor of crosscutting forms of social organization. Such a strategy seeks to undermine specifically ethnic forms of group making in favor of identification with groups such as a local community or, conversely, a cosmopolitan or global conception of identity and belonging (Wimmer 2013, 61).

\section{Strategies of Ethnic Boundary Making in the Republic of Turkey}

Wimmer's approach provides a powerful analytic explaining how and why actors choose specific modes of boundary formation and the means by which they pursue them. Such a model is extremely fruitful in the Turkish context, as it provides a theoretical mechanism that helps explain the seemingly paradoxical focus on both ethnic and civic forms of national identification in Turkey. Indeed, a close historical analysis of the national formation of Turkey reveals that ethnic and political actors pursued all of the strategies that Wimmer identifies, processes that were the result of the particular characteristics of the social field of Turkish nationalism. Institutions, power, and networks all played a critical part in the development of Turkey's national boundaries. The rise of nationalism as a potent political ideology throughout the Eastern Mediterranean in the late Nineteenth and early Twentieth Centuries spurred ethnogenesis and forced minority and majority populations in the region to reconceptualize their own ethnicity and nationality. The hierarchy of power within the late Ottoman Empire and actors' political positions within that hierarchy played a powerful role in determining which strategies were available to various political actors. Finally, the extent of political networks determined which populations would be considered part of the new nation and which would fall outside it, separating the former Ottoman population into "Turks" and "others." Within such constraints, political actors in Turkey pursued all of the various strategies of ethnic boundary formation that Wimmer enumerates. Nationalist politicians in Turkey sought to expand the boundaries of the new nation by crafting a new sense of Turkish identity, while at the same time contracting the boundaries of the nation by excluding Christians and Jews from the new national community. Similarly, actors sought to transvalue social categories, arguing for the inversion of the political and ethnic hierarchy in a way that would lead to political advantage. Meanwhile individual actors sought to move between ethnic and national groups through processes of conversion and re-identification with alternate social groups, and blurring the boundaries between them. Ultimately, political actors at both the collective and individual level utilized boundary making strategies that could help them secure advantages in political and social power. The seemingly contradictory nature of Turkey's various efforts to develop both civic and ethnic conceptions of the nation was a consequence of such attempts, as Turkish political and social actors sought to craft a new conception of Turkish national identity, establishing ethnic and national boundaries in a way that would maximize individual and collective social and political power.

\section{Characteristics of the Institutional Field}


The transition from the Ottoman Empire to the Turkish nation entailed a significant retooling of conceptions of group and individual identity. Before the advent of the Turkish nation there was little concept of a specifically Turkish ethnicity. Indeed, the term "Turk," was often used as a slur, to denigrate those seen to be rural, poor, and lacking the cultured touch of Ottoman high society (B. Lewis 1961, 1). Instead, most elites associated themselves with a cosmopolitan Ottoman identity, while many of the common people defined their collective identities, when they bothered to do so at all, in confessional terms, describing themselves as Muslims or Christians rather than emphasizing ethnicity or nationality (Freitag 2014). The rise of nationalism throughout the Nineteenth century challenged this status quo as various subject peoples of the empire discovered new ethnic and national forms of collective identification. Spurred by ideological trends originating in Western Europe, Greece and other Balkan states broke away from the Ottomans, citing principles of religious, ethnic, and national political selfdetermination (Stamatopoulos 2011). These movements and the ten years of conflict that began with the Balkan Wars in 1912 and ended with the Ottoman Empire's defeat in WWI during 1922 played a powerful role in shaping Ottoman Muslim, and later Turkish conceptions of national identity. The framing of such conflicts in religious terms caused an increasing polarization of identity in Anatolia, lending religious identities a political charge and straining inter-communal relationships that had long been relatively peaceful (Doumanis 2013). Increasingly, religion became a powerful defining line between those considered loyal to the nation and those perceived to be a threat. As Hasan Kayali has argued, the Young Turks appealed to Islam to "safeguard the unity and continuity of what was left to the empire. Islam became the pillar of the supranational ideology of Ottomanism, with religion imparting a new sense of homogeneity and solidarity (Kayali 1997, 15). Indeed, the Balkan Wars entailed significant amounts of ethnoracially motivated violence and terror, and hundreds of thousands of Muslim refugees fleeing former Ottoman possessions in the Balkans for safer conditions in Anatolia brought with them heartbreaking stories of Christian violence against Muslims, further increasing religious tensions and arousing Muslim suspicion towards Christian minority populations in what remained of Ottoman territory (Suny 2015, 185). Such concerns were reinforced and seemed justified with the Ottoman Empire's defeat in WWI, the Allies' occupation of Istanbul, and a Greek invasion bent on annexing much of western Anatolia. The religious nature of the conflicts in the Balkans and the religious overtones taken on by WWI and the Turkish War of Independence would play a powerful role in determining where the boundaries of new Turkish nation would be established (Akturk 2015).

Faced with the collapse of the cosmopolitan Ottomanism most elites had cultivated, Turkish nationalists were forced to craft a new sense of collective identity, one that could be based on common characteristics that would promote national cohesion among what remained of the Ottoman populace. Turkish nationalists seeking to define and strengthen a distinctly Turkish nation turned to the conception of the simple, rural, and traditional Turk as a central facet of identity. Recognizing the importance of a strong ethnic core around which to construct a national community, Turkish politicians and nationalist ideologues crafted one that would emphasize a 
distinct racial, cultural, linguistic, and especially religious tradition. Though they differed in the specifics, writers such as Ziya Gökalp and Yusuf Akçura, considered two of the founders of Turkish nationalist ideology, worked to define the boundaries of Turkishness. For Akçura, the emphasis was to be on race, and he argued that a policy privileging ethnic Turkism would provide the strongest foundation for the new Turkish nation as "the Turks in the Ottoman Empire [would] be bound by religious and ethnic ties" (Akçura and Fehmi 1981, 18). Gökalp favored a cultural approach, envisioning a nation "composed of individuals who share a common language, religion, morality, and aesthetics" (Gökalp 1968, 15). Atatürk himself made similar efforts, defining a distinct version of Turkish national history in his famous Nutuk, a six-day 36 hour speech in which he set out the historical narrative on which the Turkish nation would be built. The national narrative Atatürk developed sought to reveal the processes by which the great Turkish people had roused themselves from slumber, thrown off the twin shackles of Western imperialism and Ottoman decadence, and begun to take their proper place among the leading civilizations of the world. "In these circumstances," he argued "one resolution alone was possible, namely to create a New Turkish State, the sovereignty and independence of which would be unreservedly recognized (Atatürk 1981, 9)." Indeed, Atatürk explained, such a process was necessary to "ensure the development and restoration of the nation" itself (Atatürk 1981, 11). Approaches such as those pursued by Akçura, Gökalp, and Atatürk himself highlight the increased emphasis on developing a distinct ethnicity, nationality, and state for the Turkish people, a process driven largely by the rise to prominence of nationalism as a defining political ideology in Turkey and abroad.

If the rise of nationalism was the aspect of the political field that demanded the creation of a distinct Turkish ethnic and national identity, it was the power distribution in the field and the reach of political ties across the political hierarchy that would determine where its boundaries would be placed, and on which characteristics the new identification would center. Despite the dramatic change that accompanied the transition from empire to republic, many of the Sunni Muslim elites who held privileged positions in the late Ottoman Empire were able to maintain them, and played an important role in politics and policy formation in the early years in the Turkish republic (Zürcher 2010). Elite networks radiated outward from a cosmopolitan Ottoman upper class in Istanbul and extended to include a variety of powerful political actors in the outlying provinces. These elites were largely Sunni Muslim and conservative, and even the radical secularists who took control of the state during and after Atatürk's revolution were forced to come to grips with the power of preexisting systems of elite networks (Meeker 2002). Crucially, this political network did not extend outside of the Muslim ingroup, while Christians and Jews had often achieved financial and political success, during the Ottoman Empire, the polarization of identity along religious lines closed off access to power. The Ottoman Parliament, had had dozens of Christian and Jewish members but when it was reformed as the Grand National Assembly of Turkey in 1920, there was not a single non-Muslim among the 337 members of parliament (Akturk 2015, 789). Indeed, members of parliament were elected on the basis of an electoral law that allowed only Muslims to vote or run for election (Göçek 2015, 
299). Similarly, during their purge of Armenians in 1915, the CUP issued orders removing Armenian officers and governmental employees from positions of power (Suny 2015, 244, 255). Suny recounts how, as the genocide unfolded, the Armenian Patriarch attempted to meet with Talat Paşa, the Ottoman Interior Minister, "but the minister would no longer see him" (Suny 2015, 317). Even Grigor Zohrap, a prominent Armenian Member of the Ottoman Parliament who pled for the Armenians to be spared and played cards with Talat the night before Talat signed the Armenian deportation orders "as if the Ottomanist connections between Armenians and Muslims were still intact" was arrested and murdered shortly thereafter (Suny 2015, 278).

The extent of elite political networks within the Ottoman Empire had a powerful effect on the distribution of power within the political field. Though power had always been unbalanced in the Ottoman Empire, heavily favoring Sunni Muslims over Christians, Jews, and Alevis, religious polarization and conflict led to less interaction across confessional boundaries, significantly heightening the disparity. As Suny has argued, Christians' "social interactions were primarily with people in their own millet rather than with those outside with whom they were unlikely to worship or marry or even bathe in the same hamam. Members of Ottoman minorities developed social interactions with other non-Muslims or with Europeans resident in the larger cities" (Suny 2015, 46). The breakdown in intercommunal contact only increased as time went on. Ottoman policies removing Christians from positions of power, confining Christians soldiers to brutal labor battalions, and eventually, the genocide of Armenians and the removal of most Greek Christians significantly strained intercommunal networks and left Sunni Muslim Turks in complete control. The political hierarchy in the Turkish social field determined which actions specific political actors were able to take. The concentration of power in the hands of a largely Sunni elite meant that they were able to define the official boundaries of Turkishness, expanding, contracting, and blurring them at will, in a way that benefited Sunni Muslims above and beyond religious minorities. Christians, Jews, and minority Muslim populations, in contrast, occupying rungs lower in the political hierarchy were forced to resort to boundary processes that took place on a more individual level, seeking to cross and change the meaning of boundaries in a way that would provide them some advantage in a political field that was slanted against them.

\section{Strategies of Ethnic Boundary Making in Turkey}

The specific context of the Turkish political field determined the type and extent of boundary-making strategies available to elites and common people in the new state. Faced with a need to imagine a new ethno-national community, Turkish nationalists used a variety of methods to extend membership in the nation to those they wanted to incorporate, while simultaneously crafting strong ethnic and national boundaries that would exclude those they didn't. Various actors within the Turkish political field pursued all of the strategies Wimmer identified. Nationalists sought to blur pre-existing social boundaries by emphasizing cross-cutting levels of social cleavage, focusing on the new national, rather than earlier religious, ethnic, and linguistic categories. In response, individual residents of Turkey often sought to cross the newly inscribed ethno-national boundaries, learning Turkish, converting to Islam, and adopting fiercely 
nationalist political positions (Çağaptay 2003, 609). Simultaneously, nationalists sought to transvalue categories of identification, transforming the concept of "Turk" to refer, not to poor rural peasants, but to the new Turkish community itself. Indeed, one official campaign explicitly referenced this transvaluation, arguing "How Happy to Call Oneself a Turk!" in the new Turkey (Brockett 2011). Most important for our particular focus - understanding the dual nature of the Turkish government's nationalist policies - however, are Wimmer's first two strategies of ethnic boundary making, those of expansion and contraction. Careful analysis of such policies reveals that Turkish nationalists pursued both such strategies, expanding and contracting ethnonational boundaries in a manner that specifically targeted particular populations of the postOttoman population of Turkey. The simultaneous pursuit of various strategies of ethnic boundary-making explains much of the seemingly paradoxical nature of Turkish national policies in its early years, as the state simultaneously sought to impose an inclusionary civic national identity through exclusionary means. Of key importance throughout was the constant effort to maximize potential benefit for the ethno-national group and, within it, for individuals within the hierarchy of political power.

Turkish nationalists' efforts to craft a secular and civic identity represent an attempt to expand the boundaries of the new nation-state, forging a national identity that could incorporate citizens of a variety of ethnic and linguistic backgrounds. Such efforts began at the top in Atatürk's own work, who in his speeches and writings sought to present a historical narrative of the Turkish nation and define the foundational elements on which the new nation would be built. He explicitly laid out the basic characteristics of Turkish national identity, arguing that:

These are the historical and natural facts regarding the basis of the Turkish nation:

a) Political unity; b) linguistic unity; c) territorial unity; d) unity of lineage and roots; e) shared history; f) shared morality (Tezcan 1989, 20).

Such a neat delineation of the characteristics of national identity seems relatively straightforward. People who were born in Turkey, spoke Turkish, were of Turkish background, and participated in Turkish politics were theoretically to be accorded full membership in the nation. Atatürk elaborated on his vision of what the Turkish national community should encompass, emphasizing the importance of establishing the nation's borders in line with its "natural frontiers" defined by their defensibility, not by concerns such as unifying the Turkish peoples or establishing a union of all Muslims (Armstrong 1932, 218-219). The frontiers of which Atatürk spoke were to enclose primarily the lands of the Anatolian peninsula, and it was residence within such boundaries that would determine Turkish citizenship. Atatürk was clear that though the new Turkish state would enclose certain populations of religious and ethnic minorities, especially Christians, with whom the nationalist movement had had a complicated antagonistic, and even violent relationship (Akçam 2006; Gingeras 2009), the new state would treat them well. He argued "The humane attitude which we shall adopt towards the Christian population dwelling in our country will be... conclusive evidence of the civilizing factors existing in the character of our race" (Poulton 1997, 94). The first Turkish constitution, instituted 
in 1924, codified such a perspective, establishing the Republic of Turkey as a democratic secular republic and guaranteeing liberty to all citizens of Turkey (Turkish Information Office 1949). Indeed, the constitution was very careful to note that "The people of Turkey, regardless of religion and race, are Turks as regards citizenship" and continues on by saying "any person granted Turkish citizenship by law, is a Turk" (Article 88, Turkish Information Office 1949, 16).

Some of the policies instituted by the early Turkish government seemed to live up to this emphasis on civic definitions of the Turkish nation. During the first decades of the new Republic of Turkey Atatürk and his successors put into place a variety of political and social reforms designed to create a distinctly modern form of Turkish state. Though religion had served as the most important characteristic of identity and means of social organization under the Ottoman Empire, Atatürk regarded the transition from religious community to secular nationstate to be essential to Turkey's efforts to "live as an advanced and civilized nation in the midst of contemporary civilization" (Ahmad 1993, 53), and secularism became the official policy of the Turkish state. The millet system that had prevailed during the Ottoman Empire provided for different religious communities to be ruled separately, as semi-autonomous separate entities under the nominal control of the Sultan's central government. The new Turkey abolished the Caliphate and the Millet system in 1924, however, formally dismantling religion's role as a key facet of political life and official organization. Henceforth members of all religious communities would theoretically be subject to the same laws and practices, ending centuries of differential treatment based on religious background. Simultaneously, the new Turkey established the Directorate of Religious Affairs (the Diyanet Işleri Başkanlığg, often referred to simply as the Diyanet). Formally, the Diyanet's function was "to execute the works concerning the beliefs, worship, and ethics of Islam, enlighten the public about their religion, and administer the sacred worshiping places" (Adanali 2008, 232). In practice, it represented an effort to bring religion under the control of the central government. Such efforts sought to make religious practice a function of the state, and established a distinctively Turkish form of secularism in which religion was state run but rigorously segregated from the practice of government (Tank 2005).

Ostensibly, such a system would not only corral the power of Islam as a social and political force, but would provide for a more equitable society for members of all religious groups. In reality, it provided a way to consolidate the revolutionary nationalists' control over Turkish society and limit the power of a religious institution and elite that had had immense influence under the Ottoman system and looked unfavorably on Atatürk's efforts to transform Turkish society.

Within a decade, policies of language reform were created which urged all citizens to speak Turkish and reconfigured the Turkish language, stripping it of its Arabic and Persian loan words and transforming the Turkish alphabet from an Arabic to a Latin base. While linguistic nationalism has often been seen as a form of ethnic or cultural nationalism, in the Turkish case it represented an effort to craft a new political community in which all members of the state could partake, rather than an effort to return to a time of cultural purity, as in prototypical linguistic nationalist movements (Cf. Fichte 1968; Herder 2002). Critically, the Turkish language reform 
significantly weakened the connection between Turkey and both Islam and its own Ottoman past (Aslan 2007), a concrete political goal for a movement seeking to draw distinct contrasts between the new modern secular nation and its religiously oriented past and neighbors alike. In addition, such efforts also worked to better integrate the elite, who had spoken a more literary version of Ottoman Turkish, with the common people, who spoke a vernacular form of "rough Turkish." Simultaneously, the government launched a "Citizen, Speak Turkish!" campaign designed to pressure non-Turkish speaking members of minority communities to better conform to the new Turkish norm. Non-Turkish speakers constituted roughly $28 \%$ of the Turkish population (Dündar 1999, 157), and the organizers of the campaign believed that those who could not speak Turkish would not have access to political and social life, and thus would fail to be good citizens. Though policies designed to encourage such homogenization appear (and indeed were) discriminatory, their ultimate goal of incorporating various minority populations within an overarching conception of Turkish identity reveals a distinct focus on integration within a civic community. Indeed, "the state elite thought that a common language was necessary to make people think and feel alike" (Aslan 2007, 251). Policies such as the 1924 Law on the Unification of Education, which brought all schools under centralized government control, and statutes designed to promote the teaching of the Turkish language in all schools and its use in business in 1926 and 1931 respectively further reveal the state's emphasis on linguistic conformity (Aslan 2007, 251). Turkish nationalists thus follow the approach Wimmer defines as the "integrationist" approach to nation-formation, identifying and/or constructing a central ethnic identification and urging all other residents of the state to conform to the boundaries of that ethnic identity and thus form a new national community (Wimmer 2008b, 1032). In the case of Turkey, national boundaries were to be extended to encompass those perceived as willing to integrate themselves within an explicitly ethnic Turkish definition of the nation, incorporating minorities only to the extent that they were "Turkified" and unsupported by powerful allies outside of Turkey, while excluding those populations perceived to have powerful backing from foreign states (Mylonas 2012)

Indeed, policies which privileged Sunni Muslim Turks did not cease with the collapse of the Ottoman Empire. Significant levels of violence accompanied the reconfiguration of the Ottoman state into the Turkish nation, as Turkish nationalists took steps to purge the new nation of ethnic and religious minorities, contracting the boundaries of the new nation to an ethnonational core of Muslim Turks. Following the collapse of imperial power many Turks viewed the remaining populations of religious minorities within Turkish territory a dangerous threat to the new nation. Communities of Christians were seen as particularly suspect, due to their religious and political links to foreign nations such as Greece, Britain, France and Italy, several of which had invaded Turkey during the end of WWI, as well as Russia, which had close ties to Armenian populations in eastern Anatolia. Such foreign connections were seen as a barrier to the construction of a true national community. As Hüseyin Cahit Yalçin, a journalist who often expressed the opinions of Committee of Union and Progress, argued "For the State... [and] the Constitutional Regime, the greatest danger came from the non-Turkish elements within Ottoman 
Society" thus "the history of the Constitutional period is the history of the Turks, who perceived the danger, and struggled not to drown in the flood of peoples" (Akçam 2006, 56). Turkish efforts "not to drown in the flood" provide the strongest evidence of the constriction of national boundaries, drawing the borders of the national community in a way that deliberately did not include populations that theoretically should have been welcomed as members of a new civic nation. In the east of Anatolia between 800,000 and 1.5 million Armenians were deported and massacred in 1915. As Halil Menteşe, an influential member of the CUP argued "Had we not cleansed our Eastern Provinces of Armenian revolutionaries collaborating with the Russians, there would have been no possibility of establishing our national state" (Akçam 2006, 122). These policies, now widely regarded by the international and scholarly community as genocidal, though the Turkish government continues to refute the claim (Göçek 2015), were matched by the treatment of Greek Orthodox Christians in the Pontic region, who were similarly evicted from their homes and faced forced death marches and executions (Photiades and Eleftheriou 2015; Tsirkinides 1999). Meanwhile, Greek Orthodox Christians in western Turkey became subject to an enforced population exchange with Greece, in which the remaining Christians living in Turkey who had not fled with the Greek army would be sent to Greece, in exchange for Muslims who lived within Greece's national borders (Clark 2006; Yildirim 2006). Throughout, the Turkish nationalist movement's concern was for the homogenization of the Turkish homeland, removing minority populations that did not share the Turkish culture, ethnicity, or religion, key factors on which the new nation would be based, and were thus deemed unassimilable.

Efforts to contract religious boundaries persisted long after Turkey's founding moment, however, and continued to center around religious minorities as, despite Atatürk's stated intentions to the contrary, religion maintained a powerful role in Turkish social organization. Immigration policies throughout the 1930s privileged Muslim immigrants over non-Muslims, even those who had once lived in the Ottoman lands that would become Turkey before being driven out by the vast upheavals of the 1920s (Çağaptay 2006, 65). Laws permitting only Turks to own magazines and journals ("Matbuat Kanunu [The Press Law]" 1931), banning non-Turkish citizens from a large variety of occupations ("Türkiye'de Türk Vatandaşlarina Tahsis Edilen Sanat ve Hizmetler Hakkinda Kanun [Law on Professions and Services Allocated to Turkish Citizens in Turkey. Nr, 2007" 1932), and another prohibiting the establishment of organizations and associations representing ethnic and religious minorities ("Cemiyetler Kanunu [Law on Associations]" 1983), all served to restrict full membership in the Turkish nation to an ethnically and religiously homogenous core population. Other policies placed even heavier burdens on nonTurkish members of Turkish society. In 1942, in preparation for an anticipated entry into World War II, the government passed a fundamentally unequal Wealth Tax (Varlik Vergisl). The tax was nominally assessed on all residents of Turkey, but taxed non-Muslims at drastic rates, while assessing insignificant rates on Muslim populations (Çetinoglu 2012). Elements of the Turkish government went even further, planting a bomb outside Atatürk's historic house in Salonica in an effort to stir up ethnic and racial tensions. Riots and pogroms soon swept Istanbul, as thousands of shops, homes, churches, and cemeteries owned by Christians and Jews were burned 
and destroyed (Kuyucu 2005, 362). Those with religious and political ties elsewhere, however faint, could not be Turks, and must needs fall outside the boundaries of Turkishness. Efforts to constrict Turkish national boundaries began with the expulsion and massacre of large populations of Armenians and Greek Orthodox Christians at Turkey's founding. Those minorities who survived and remained in Turkey, especially small Christian populations in Istanbul, faced continued prejudice for decades to come, as they were considered to be not truly members of the Turkish community. The constriction of Turkish national boundaries, drawing them in ways which deliberately excluded minority populations, reveals an effort to maximize the political benefits for a closely defined ethno-religious core population of Turks.

\section{Conclusions}

The relationship between civic and ethnic conceptualizations of national identity has been one of the defining questions of Turkish politics since, and even before, the founding of the Republic of Turkey in 1923. Successive generations of Turkish policy making have implemented policies that have emphasized both exclusionary and inclusive definitions of the national community. Efforts to transform society, discarding linguistic and religious differences that had proved divisive in the late Ottoman Empire represented a real effort to forge a cohesive national community, one defined primarily in secular and civic terms. Revolutionary nationalists in the first decades of the Turkish Republic pursued policies designed to modernize and Westernize Turkish society, building a new nation on the model of civic European societies such as France. Turkish nationalists believed that Turkey could only take its proper place as a leading society on the world stage by adopting Western ideas of citizenship and belonging, and so the policies of the new Turkish state sough to mold a diverse and multinational Ottoman society, whose populations were defined primarily in ethnic and religious terms, into a modern Western society in which all residents of the state could be true "Turks." Policies designed to expel religious and ethnic minorities and discriminatory politics intended to disadvantage those who remained, reveal a powerful exclusionary streak in the new nation, however, as Turkish nationalists sought to purge those they considered unfit for or unwilling to join the new explicitly Turkish national community. Populations with close ties, real or imagined, to the foreign Christian powers that had so recently defeated and invaded Turkey were automatically suspect, and considered too dangerous to join the national community. Turkish nationalists thus carefully shaped the borders of their new nation, extending it to those populations thought to be assimilable while excluding those thought to be threats to national unity.

This article has sought to provide a theoretical framework to explain how and why efforts to create a new Turkish nation relied upon exclusionary policies despite an inclusivist civic rhetoric. I argue that it was an emphasis on ethnic and national boundaries that prompted Turkish nationalists to pursue policies that seem paradoxical at first glance. Closer analysis of the Turkish state's simultaneous emphasis on inclusiveness on some dimensions and exclusivity on others reveals a concerted effort to maximize the strength of the Turkish nation's social and political boundaries. For a new nationalist movement struggling to throw off the dual yoke of 
Western invasion and ineffective Ottoman governance, such boundaries were of crucial importance. The new Turks needed to explicitly define who and what they would be, while simultaneously deciding who would not be members of the nation. Ultimately, Turkish nationalists sought to maximize political gain, instituting polices that they felt would craft a coherent and intrinsically bounded sense of national identity, one to which the Turkish population would be dedicated. Such efforts to maximize gain for a distinct and bounded Turkish nation meant that, despite the nationalist movement's civic and inclusivist rhetoric strategies that killed, expelled, and discriminated against minority populations thought to fall outside the new national boundaries remained prominent in Turkish nationalist policy making.

An ethnic boundary-making approach provides analytical tools to help understand how such complex decisions of national belonging were made. The strength and extent of the nation's boundaries were determined by the conditions of the Turkish political field. The need to craft a new nation-state, the extent of political networks, and the relative power of political actors within the system led Turkish nationalists to construct more restrictive boundaries than might have been expected from the inclusivist rhetoric championed by Mustafa Kemal Atatürk and his revolutionary colleagues. Turkish policy makers drew national boundaries that extended as far as their political networks did, using their positions of power within the social field to incorporate certain populations while excluding others. Guided by the structures and conditions of the social field, Turkish nationalists pursued polices that directly manipulated national boundaries, to both incorporate those populations thought to be assimilable while simultaneously categorically excluding those perceived to hold allegiances to external nations and states. This analysis thus reveals the efficacy of an ethnic-boundary making approach for scholars seeking to transcend the classic ethnic/civic paradigm of nationalism studies. Scholars of Turkish nationalism, as those in many places, have traditionally focused on Turkey's ethnic or civic characteristics, arguing that the Turkish nation is either one or the other. Such a simplistic dichotomy conceals the reality that Turkish nationalists have pursued policies that focus on both civic and ethnic dimensions of the nation. Analyzing nationalist policies through a boundary-making framework, however, allows us to understand how and why nationalists pursued the strategies they did. Such an approach reveals that the seemingly contradictory nature of Turkish nationalism, pursuing exclusionary politics while preaching inclusive rhetoric, is not paradoxical at all. Rather such efforts represent multiple dimensions of the same project, as nationalists pursued any means necessary in their efforts to craft a cohesive new national community, one with strong boundaries and a powerful sense of political loyalty to the nation. 


\section{Works Cited}

Adanali, Ahmet Hadi. 2008. "The Presidency of Religious Affairs and the Principle of Secularism in Turkey." Muslim World 98 (2/3).

Ahmad, Feroz. 1993. The Making of Modern Turkey. London; New York: Routledge.

Ahmad, Feroz. 2003. Turkey: The Quest for Identity. Oxford: Oneworld.

Akçam, Taner. 2006. A Shameful Act : The Armenian Genocide and the Question of Turkish Responsibility. New York: Metropolitan Books.

Akçam, Taner. 2012. The Young Turks' Crime against Humanity: The Armenian Genocide and Ethnic Cleansing in the Ottoman Empire. Princeton, N.J.: Princeton University Press.

Akçura, Yusuf, and Ismail Fehmi. 1981. "Yusuf Akçura's Uç Tarzi Siyaset ('Three Kinds of Policy')." Oriente Moderno 61 (1/12): 1-20.

Akman, Ayhan. 2004. "Modernist Nationalism: Statism and National Identity in Turkey." Nationalities Papers 32 (1).

Akturk, Sener. 2009. "Persistence of the Islamic Millet as an Ottoman Legacy: Mono-Religious and AntiEthnic Definition of Turkish Nationhood." Middle Eastern Studies 45 (6): 893-909.

Aktürk, Sener. 2012. Regimes of Ethnicity and Nationhood in Germany, Russia, and Turkey. New York: Cambridge University Press.

Akturk, Sener. 2015. "Religion and Nationalism: Contradictions of Islamic Origins and Secular NationBuilding in Turkey, Algeria, and Pakistan*." Social Science Quarterly 96 (3): 778-806.

Al, Serhun. 2015. "An Anatomy of Nationhood and the Question of Assimilation: Debates on Turkishness Revisited." SENA Studies in Ethnicity and Nationalism 15 (1): 83-101.

Al, Serhun, and Daniel Karell. 2016. "Hyphenated Turkishness: The Plurality of Lived Nationhood in Turkey." Nationalities Papers 44 (1): 144-164.

Armstrong, H. C. 1932. Grey Wolf: Mustafa Kemal - An Intimate Study of a Dictator. London: A. Barker, Ltd.

Aslan, Senem. 2007. "'Citizen, Speak Turkish!': A Nation in the Making." Nationalism and Ethnic Politics 13 (2): 245-272.

Atatürk, Kemal. 1981. A Speech Delivered by Mustafa Kemal Atatürk, 1927. Istanbul: Basbakanlik Basimevi.

Aytürk, Ilker. 2004. "Turkish Linguists against the West: The Origins of Linguistic Nationalism in Atatürk's Turkey." Middle Eastern Studies 40 (6): 1-25.

Barth, Fredrik. 1969. "Introduction." In Ethnic Groups and Boundaries. The Social Organization of Culture Difference., edited by Fredrik Barth. Boston: Little, Brown.

Berkeş, Niyazi. 1964. The Development of Secularism in Turkey. Montreal: McGill University Press.

Bora, Tanil. 2003. "Nationalist Discourses in Turkey." South Atlantic Quarterly 102 (2/3).

Brockett, Gavin D. 2011. How Happy to Call Oneself a Turk: Provincial Newspapers and the Negotiation of a Muslim National Identity. Austin: University of Texas Press.

Brubaker, Rogers. 1992. Citizenship and Nationhood in France and Germany. Cambridge, Mass.: Harvard University Press. 
Brubaker, Rogers. 1999. "The Manichean Myth: Rethinking the Distinction Between 'Civic' and 'Ethnic' Nationalism." In Nation and National Identity: The European Experience in Perspective, edited by Hans Kriesi et al. Zurich: Ruegger.

Brubaker, Rogers. 2006. Nationalist Politics and Everyday Ethnicity in a Transylvanian Town. Princeton: Princeton University Press.

Brubaker, Rogers. 2014. "Beyond Ethnicity." Ethnic and Racial Studies 37 (5): 804-808.

Çağaptay, Soner. 2003. "Citizenship Policies in Interwar Turkey." Nations and Nationalism 9 (4): 601619.

Çağaptay, Soner. 2006. Islam, Secularism, and Nationalism in Modern Turkey: Who Is a Turk? London; New York: Routledge.

“Cemiyetler Kanunu [Law on Associations]." 1983. In TBMM Zabit ceridesi, 26:412-417. V. Ankara: Büyük Millet Meclisi.

Çetinoglu, Sait. 2012. "The Mechanisms for Terrorizing Minorities: The Capital Tax and Work Battalions in Turkey during the Second World War." Mediterranean Quarterly 23 (2).

Clark, Bruce. 2006. Twice a Stranger: The Mass Expulsions That Forged Modern Greece and Turkey. Cambridge, Mass.: Harvard University Press.

Doumanis, Nicholas. 2013. Before the Nation: Muslim-Christian Coexistence and Its Destruction in Late Ottoman Anatolia. Oxford: Oxford University Press.

Dündar, Fuat. 1999. Türkiye Nüfus Sayimlarinda Azinliklar. Beyoglu, Istanbul: Doz Yayinlari.

Fichte, Johann Gottlieb. 1968. Addresses to the German nation. New York: Harper \& Row.

Freitag, Ulrike. 2014. “'Cosmopolitanism' and 'Conviviality'? Some Conceptual Considerations Concerning the Late Ottoman Empire." European Journal of Cultural Studies 17 (4): 375-391.

Gingeras, Ryan. 2009. Sorrowful Shores: Violence, Ethnicity, and the End of the Ottoman Empire, 19121923. Oxford; New York: Oxford University Press.

Göçek, Fatma Müge. 2015. Denial of violence: Ottoman past, Turkish present, and collective violence against the Armenians, 1789-2009.

Gökalp, Ziya. 1968. The Principles of Turkism. Translated by Robert Devereaux. E.J. Brill.

Grigoriadis, loannis N. 2013. Instilling Religion in Greek and Turkish Nationalism : A "Sacred Synthesis." Palgrave Macmillan: New York.

Hanioğlu, M. Sükrü. 2011. Atatürk: An Intellectual Biography. Princeton: Princeton University Press.

Herder, Johann Gottfried. 2002. Philosophical writings. Translated by Forster Michael N. Cambridge, UK; New York: Cambridge University Press.

Kayali, Hasan. 1997. Arabs and Young Turks : Ottomanism, Arabism, and Islamism in the Ottoman Empire, 1908-1918.

Kili, Suna. 1983. Atatürk Devrimi : Bir Çağdaşlaşma Modeli. [Ankara]: Türkiye Is Bankasi Kültür Yayinlari. Kirişci, Kemal. 2000. "Disaggregating Turkish Citizenship and Immigration Practices." Middle Eastern Studies. 36 (3): 1.

Koçan, Gürcan, and Ahmet Üncü. 2004. "Citizen Alevi in Turkey: Beyond Confirmation and Denial." Journal of Historical Sociology 17 (4): 464-489.

Kohn, Hans. 1944. The Idea of Nationalism: A Study in Its Origins and Background. New York: Macmillan Co. 
Kuyucu, Ali Tuna. 2005. "Ethno-Religious 'unmixing' of Turkey: 6-7 September Riots as a Case in Turkish Nationalism." Nations and Nationalism 11 (3): 361-380.

Lewis, Bernard. 1961. The Emergence of Modern Turkey. London, New York: Oxford University Press.

Lewis, Geoffrey. 1999. The Turkish Language Reform : A Catastrophic Success. Oxford; New York: Oxford University Press.

“Matbuat Kanunu [The Press Law]." 1931. In Düstur (Code of Laws), 12:369, 366-380. Third Set. Ankara: Türkiye Büyük Millet Meclisi.

Meeker, Michael E. 2002. "A Nation of Empire the Ottoman Legacy of Turkish Modernity." http://site.ebrary.com/id/10050794.

Morin, Aysel, and Ronald Lee. 2010. "Constitutive Discourse of Turkish Nationalism: Atatürk's Nutuk and the Rhetorical Construction of the 'Turkish People.'" Communication Studies 61 (5): 485-506.

Mylonas, Harris. 2012. The Politics of Nation-Building : Making Co-Nationals, Refugees, and Minorities. New York: Cambridge University Press.

Pearson, David. 2000. "The Ties That Unwind : Civic and Ethnic Imaginings in New Zealand." Nations and Nationalism : Journal of the Association for the Study of Ethnicity and Nationalism.

Photiades, Kostas, and Michael Eleftheriou. 2015. The Genocide of the Pontian Greeks.

Poulton, Hugh. 1997. Top Hat, Grey Wolf, and Crescent: Turkish Nationalism and the Turkish Republic. London: C. Hurst \& Co. (Publishers) Ltd.

Shulman, Stephen. 2002. "Challenging the Civic/Ethnic and West/East Dichotomies in the Study of Nationalism." Comparative Political Studies 35 (5): 554-585.

Shulman, Stephen. 2004. "The Contours of Civic and Ethnic National Identification in Ukraine." EuropeAsia Studies. 561: 35-56.

Smith, Anthony D. 1987. The Ethnic Origins of Nations. Oxford, UK; New York, NY, USA: B. Blackwell.

Smith, Anthony D. 1991. National Identity. Reno: University of Nevada Press.

Stamatopoulos, Dimitris. 2011. Balkan nationalism(s) and the Ottoman Empire.

Suny, Ronald Grigor. 2015. "They Can Live in the Desert but Nowhere Else" : A History of the Armenian Genocide. Princeton, N.J.: Princeton University Press.

Tank, Pinar. 2005. "Political Islam in Turkey: A State of Controlled Secularity." Turkish Studies 6 (1): 3-19. Tezcan, Nurhan, ed. 1989. Atatürk'ün Yazdığı Yurttaşlık Bilgileri. Istanbul: Çağdaş.

Tsirkinides, Chares. 1999. At Last We Uprooted Them : The Genocide of Greeks of Pontos, Thrace and Asia Minor through French Archives. Thessaloniki: Kyriakidis Brothers.

Turan, Ilter. 1969. Cumhuriyet Tarihimiz. Beyoglu-Istanbul: aglayan Kitabevi.

Turkish Information Office. 1949. The Turkish Constitution. Turkey Today 11. New York.

"Türkiye' de Türk Vatandaşlarina Tahsis Edilen Sanat ve Hizmetler Hakkinda Kanun [Law on Professions and Services Allocated to Turkish Citizens in Turkey. Nr, 2007." 1932. In Düstur (Code of Laws), 13:649-650. Third Set. Ankara: Türkiye Büyük Millet Meclisi.

Uzer, Umut. 2011. "The Genealogy of Turkish Nationalism: From Civic and Ethnic to Conservative Nationalism in Turkey." In Symbiotic Antagonisms Competing Nationalisms in Turkey, edited by Ayse Kadioglu and Emin Fuat Keyman. Salt Lake City: University of Utah Press.

White, Jenny B. 2013. Muslim Nationalism and the New Turks. Princeton: Princeton University Press. Wimmer, Andreas. 2008a. "The Making and Unmaking of Ethnic Boundaries: A Multilevel Process Theory." American Journal of Sociology 113 (4). 
Wimmer, Andreas. 2008b. "Elementary Strategies of Ethnic Boundary Making." Ethnic and Racial Studies 31 (6): 1025-1055.

Wimmer, Andreas. 2013. Ethnic Boundary Making : Institutions, Power, Networks. New York: Oxford University Press.

Xypolia, Ilia. 2016. "Racist Aspects of Modern Turkish Nationalism." Journal of Balkan and Near Eastern Studies Journal of Balkan and Near Eastern Studies, 1-14.

Yack, B. 1996. "The Myth of the Civic Nation." CRITICAL REVIEW -CHICAGO THEN NEW YORK- 10 (2): 193-212.

Yildirim, Onur. 2006. Diplomacy and Displacement: Reconsidering the Turco-Greek Exchange of Populations, 1922-1934. New York: Routledge.

Zeydanlioğlu, Welat. 2012. "Turkey's Kurdish Language Policy." International Journal of the Sociology of Language, no. 217: 99-125.

Zürcher, Erik Jan. 2010. The Young Turk Legacy and Nation Building : From the Ottoman Empire to Atatürk's Turkey. London; New York; New York: I. B. Tauris. 